\title{
Trends of Microcephaly and Severe Arthrogryposis in Three Urban Hospitals following the Zika, Chikungunya and Dengue Fever Epidemics of 2016 in Jamaica
}

\author{
T James-Powell ${ }^{1}$, Y Brown ${ }^{2}$, CDC Christie ${ }^{3}$, R Melbourne-Chambers 3 , JT Moore ${ }^{3}$, O Morgan², B Butler ${ }^{1}$, K Swaby ${ }^{3}$, \\ A Garbutt ${ }^{3}$, J Anzinger ${ }^{4}$, RB Pierre ${ }^{3}$, A Onyonyor ${ }^{5}$, L Bryan ${ }^{6}$, PM Palmer $^{3}$, P Mitchel12, 5, P Johnson ${ }^{7}, K_{\text {B Bishop }}^{8}$, \\ JR Jaggon ${ }^{8}$, W De La Haye ${ }^{9}$
}

\begin{abstract}
Introduction: Jamaica experienced its maiden Zika virus (ZIKV) epidemic in 2016, while dengue (serotypes 3 and 4) and chikungunya were also circulating.

Aim: We describe initial trends in microcephaly and arthrogryposis observed by the clinicians from three urban birthing facilities during late 2016 to early 2017.

Methods: Reporting of infant microcephaly was required from all birthing facilities in Jamaica. Staff were to be trained in measuring the occipito-frontal head circumference (OFC) using World Health Organization's (WHO) standards. Affected newborns were to be referred for comprehensive paediatric evaluation.

Results: Hospital A reported 15 full-term newborns with microcephaly, 10 were delivered between November 10, 2016 and January 6, 2017. All were full-term newborns with OFC ranging from 28.5 to $31.5 \mathrm{~cm}$, severe microcephaly with OFC's $<-3 Z$ scores was seen in ten. Most $(12,80 \%)$ had the characteristic craniofacial phenotype of congenital syndrome associated with Zika (CSAZ). Ten had neonatal ultrasounds which revealed intracerebral calcifications (4), dilated and/or asymmetric lateral ventricles (4), grossly overlapping sutures and/or closed or small fontanelles (3), cerebral atrophy (one) and absent frontal lobe sulcation with increased periventricular white matter (one). Computerized tomography (CT) scans revealed calcifications and dilated ventricles with thinning of cortical mantle (two others). Four mothers reported rash. The rate of microcephaly was estimated as 0.8\% (10/1212) live births. In hospital B, among $414 / 629$ (65\%) of primarily term vaginal live births reviewed during eight weeks of December to January 2017, 17 had OFCs $<32 \mathrm{~cm}$; eight patients had OFC $<-2$ Z score, six patients had $O F C<-3 Z$ score and three patients had OFC at $-2 Z$ score; 14 patients (3\%) were therefore microcephalic. Seventeen had relative microcephaly. Among the 14 microcephaly cases, five term babies had low birthweight, three had seizures within 24 hours, 6/14 were adolescents aged 15-19 years and among 11/14 with uterine ultrasonography, one was abnormal with head-body discrepancy. Two had a cranial ultrasonogram showing intracerebral calcifications, dilated lateral ventricle and cerebral atrophy. One mother reported rash in pregnancy. Microcephaly rate was 1.63\% (14/857 live births). Hospital C identified 2\% (1/43) microcephaly rate (OFC $<31.4$ $\mathrm{cm}<-2$ Z scores) amongst symptomatic mothers during May 1, 2016 through March 31, 2017. Four others had low OFCs $(<33 \mathrm{~cm})$, but not in the range for microcephaly. Therefore, $84 \%$ (36/43) of babies born to symptomatic mothers had normal OFC. Microcephaly rate for all live births for the period was $2.2 \%$ (26/1180). The monthly rate varied from $0 \%$ to $5 \%$ (6/118) peaking in March. Of two babies referred with severe arthrogryposis and microcephaly, one had characteristic evidence on nuclear magnetic resonance imaging of corpus callosum dysgenesis, occipital lobe cyst, cerebellar hypoplasia and intracranial calcifications. In the other, CT scan
\end{abstract}

From: ${ }^{1}$ Department of Pediatrics, Spanish Town Hospital, ${ }^{2}$ Victoria Jubilee Maternity Hospital, ${ }^{3}$ Department of Child and Adolescent Health (Infectious Diseases, or Neurology, or Child Development and Behaviour, The University Hospital of the West Indies, ${ }^{4}$ Department of Microbiology, The University of the West Indies, ${ }^{5}$ Department of Obstetrics, Spanish Town Hospital, St Catherine, ${ }^{6}$ Department of Obstetrics, The University Hospital of the West Indies, ${ }^{7}$ Department of Radiology (Neuro-Radiology) and ${ }^{8}$ Department of Pathology
(Perinatal or Neuro), The University of the West Indies, Kingston, and ${ }^{9}$ Ministry of Health, Kingston Jamaica, West Indies.

Correspondence: Professor CDC Christie, Department of Child (Paediatrics) and Adolescent Health, The University of the West Indies, Kingston 7, Jamaica, West Indies. Email: Celia.ChristieSamuels@uwimona.edu.jm 
of the brain revealed microcephaly with cortical atrophy, severe ventriculomegaly of the lateral and third ventricles, fine calcifications in the thalami and basal ganglia bilaterally and in the right frontal lobe, with a huge posterior fossa cyst communicating with the $4^{\text {th }}$ ventricle. He died and autopsy confirmed these findings. Cross-reactivity of serological tests for dengue and Zika virus challenged laboratory diagnosis in mothers and newborns.

Conclusion: Newborns with "characteristic CSAZ features" are being born in urban settings primarily to asymptomatic mothers in Jamaica. Diagnosis is challenged by serological crossreactivity between the circulating flaviviruses. Team management is multidisciplinary and will be a costly intervention for developing countries to implement to maximize the neurodevelopmental potential of this new and vulnerable population of children.

Keywords: Aedes aegypti mosquito, chikungunya fever, congenital syndrome associated with Zika virus, dengue fever, Jamaica, microcephaly, newborn, Zika virus

\title{
Tendencias de la Microcefalia y la Artrogriposis Severa en tres Hospitales Urbanos tras las Epidemias de Fiebre de Zika, Chikunguña y Dengue de 2016 en Jamaica
}

T James-Powell'1, Y Brown ${ }^{2}$, CDC Christie ${ }^{3}$, R Melbourne-Chambers ${ }^{3}$, JT Moore ${ }^{3}$, O Morgan ${ }^{2}$, B Butler ${ }^{1}$, K Swaby ${ }^{3}$, A Garbutt ${ }^{3}$ J Anzinger 4 , RB Pierre ${ }^{3}$, A Onyonyor ${ }^{5}$, L Bryan $^{6}$, PM Palmer ${ }^{3}$, P Mitchel12, $^{2}$, P Johnson 7 , K Bishop ${ }^{8}$, JR Jaggon ${ }^{8}$, W De La Haye ${ }^{9}$

\begin{abstract}
RESUMEN
Introducción: Jamaica tuvo su debut en la epidemia de virus del zika en 2016, cuando ya circulaban también la chikunguña y el dengue (serotipos 3 y 4).

Objetivo: Describir las tendencias iniciales de microcefalia y artrogriposis observadas por los clínicos de tres centros urbanos de parto desde finales de 2016 hasta principios de 2017.

Métodos: A todos los centros de parto en Jamaica, se les pidió reportar los casos de microcefalia infantil. Se adiestró personal para medir la circunferencia occipito-frontal (COF) siguiendo las normas de la Organización Mundial de la Salud (OMS). Los recién nacidos afectados tenían que ser referidos para evaluación pediátrica integral.

Resultados: El hospital A reportó 15 recién nacidos a término con microcefalia. Diez de ellos nacieron entre el 10 de noviembre de 2016 y el 6 de enero de 2017. Todos fueron recién nacidos a término con una COF que oscilaba de 28.5 a $31.5 \mathrm{~cm}$. En 10 de ellos se observó microcefalia severa con puntuaciones de COF <-3 Z. La mayoría (12, 80\%) tenían el fenotipo craneofacial característico del síndrome congénito asociado c el zika (SCAZ). Diez tuvieron ultrasonidos neonatales que revelaron calcificaciones intracerebrales (4), ventrículos laterales dilatados y/o asimétricos (4), suturas marca-damente superpuestas y/o fontanelas cerradas o pequeñas (3), atrofia cerebral (uno), y ausencia de surcos del lóbulo frontal con aumento de la sustancia blanca periventricular (uno). Los escaneos de tomografia computarizada (TC) revelaron calcificaciones y ventrículos dilatados con adelgazamiento de la capa cortical (otros dos). Cuatro madres habian reportado erupciones. La tasa de microcefalia se estimó en 0.8\% (10/1212) nacidos vivos. En el hospital B, entre los 414/629 (65\%) de los nacidos vivos en partos vaginales principal-mente a término, revisados durante ocho semanas de diciembre a enero de 2017, 17 tuvieron una COF $\leq 32 \mathrm{~cm}$; ocho pacientes tuvieron puntuación COF $<-2 Z$; seis pacientes tuvieron puntación COF $<-3 Z$; y tres pacientes tuvieron puntuación COF de -2 Z. Por lo tanto, 14 pacientes (3\%) eran microcéfalos. Diecisiete tenían microcefalia relativa. De los 14 casos de microcefalia, cinco recién nacidos a término tuvieron bajo peso al nacer, tres tuvieron convulsiones dentro de las 24 horas, 6/14 eran adolescentes de 15 a 19 años de edad, y entre 11-14 con ultrasonografía uterina, uno era anormal con discrepancia cabeza-cuerpo. En dos, el ultrasonido craneal mostró calcificaciones intracerebral dilatación del ventrículo lateral y atrofia cerebral. Una madre informó erupción en el embarazo. La tasa de microcefalia fue del 1,63\% (14/857 na-cidos vivos). El Hospital C identificó una tasa de microcefalia del $2 \%(1 / 43)(O F C<31.4 \mathrm{~cm}<-2$ puntuaciones Z) entre las madres sintomáticas entre el 1 de mayo de 2016 y el 31 de marzo de 2017. Otras cuatro tenían OFCs bajas (<33 cm), pero no en el rango de microcefalia. Por lo tanto, el 84\% (36/43) de los bebés
\end{abstract}


nacidos de madres sintomáticas tenían una OFC normal.

La tasa de microcefalia para todos los nacidos vivos durante el periodo fue del 2,2\% (26/1180). La tasa mensual varió de $0 \%$ a $5 \%$ (6/118) alcanzando su máximo en marzo. De los dos bebés referidos con artrogriposis y microcefalia graves, uno tenía evidencia característica de la resonancia magnética nuclear de la disgenesia del cuerpo calloso, el quiste del lóbulo occipital, la hipoplasia cerebelosa y las calcificaciones intracraneales. En el otro, la tomografía computarizada del cerebro reveló microcefalia con atrofia cortical, ventriculomegalia grave de la lateral y tercera ventrículos, calcificaciones finas en el tálamo y los ganglios basales bilateralmente y en el lóbulo frontal derecho, con un gran quiste de fosa posterior que se comunica con el $4^{\circ}$ ventrículo. Murió y la autopsia confirmó estos hallazgos. La reactividad cruzada de las pruebas serológicas para el dengue y el virus del Zika desafió el diagnóstico de laboratorio en madres y recién nacidos.

Conclusión: Los recién nacidos con "características características de CSAZ" nacen en entornos urbanos principalmente a madres asintomáticas en Jamaica. El diagnóstico se ve desafiado por la reactividad cruzada serológica entre los flavivirus circulantes. La administración del equipo es multidisciplinaria y será una intervención costosa para los países en desarrollo a implementar para maximizar el potencial de desarrollo neurológico de esta nueva y vulnerable población de niños.

Palabras claves: Mosquito Aedes aegypti, fiebre de chikunguña, síndrome congénito asociado al virus del zika, fiebre del dengue, Jamaica, microcefalia, neonatal

West Indian Med J 2017; 66 (1): 12

\section{BACKGROUND}

In November 2015, Zika virus (ZIKV) was found to be associated with infant microcephaly in Pernambuco, Brazil and Guillain Barre syndrome in Salvador, Brazil (1). After about one million cases of ZIKV-infection were identified from Brazil, the WHO declared this ZIKV outbreak a "Public Health Emergency of International Significance" on February 1, 2016 (2). The purpose was to mobilise financial resources to explore a potential link between ZIKV and microcephaly and neurological syndromes.

ZIKV, a flavivirus capable of infecting nervous tissue, has been conclusively linked to infant microcephaly from motherto-child transmission, using the Bradford Hill and Shephard's criteria for proof of human teratogenicity (3). The congenital syndrome associated with ZIKV (CSAZ) is characterized by severe microcephaly with a partially collapsed skull, intracranial calcifications, ventriculomegaly, microphthalmia, cataracts, macular atrophy, severe arthrogryposis, intrauterine growth retardation and sensorineural hearing-loss (4-8). Other perinatal features include: fetal deaths, still births and oligohydramnios, and ZIKV has been identified from fetal brain, infant brain tissue and amniotic fluid (9). The congenital syndrome associated with ZIKV is consistent with the rare "fetal brain disruption sequence", with only 20 reported cases in the world before $2001(10,11)$. However, in characterizing the first 1501 cases of CSAZ from Brazil, the authors warned that "Because many definite, or probable cases present normal head circumference values and their mothers do not report having a rash, screening criteria must be revised in order to detect all affected newborn babies" $(12,13)$.

As of March 17, 2017, the ZIKV epidemic has extended beyond Brazil, to include the Caribbean and North, Central and South America, with 84 countries/territories reporting "mosquito-borne" ZIKV transmission since 2007 and 61 with a reported "outbreak" from 2015 onwards (14). Jamaica observed its first case of ZIKV in a four-year-old child on her return from Texas, United States of America (USA), with her family in January 2016 (15). However, a recent phylogenetic study indicates that ZIKV was introduced into Jamaica in 2015 , a year prior to this first case (16). This undetected circulation of ZIKV occurred not only in Jamaica and other Caribbean Islands, but also widely throughout the Americas, including the USA (16). In the first 17 months of the epidemic to May 17, 2017, ZIKV surveillance notifications in Jamaica have approached 10187 in total, comprising, suspected cases of $7850(77 \%)$ and laboratory confirmed cases of 203 (2\%), with the epidemic peaking in June 2016 (Ministry of Health, Jamaica). We now report herein, initial trends in microcephaly and severe arthrogryposis observed by a multi-disciplinary team of practising clinicians, for three urban birthing facilities in Greater Kingston, Jamaica during the late 2016 to early 2017.

\section{MATERIAL AND METHODS}

In December, 2015, the Jamaican Ministry of Health required reporting of microcephaly in newborns and pregnant women who fit the surveillance case definition for ZIKV-infection (17-19). In May 2016, "rash only" was added to the case definition among pregnant women (15). Newborns with microcephaly were to be referred to paediatricians for comprehensive management and the CSAZ phenotype from other reports were considered (4-8).

In June 2016, the European Commission funded three consortia including "ZIKAction", to perform collaborative population-based research to better characterise the epidemic in Latin America, Caribbean, Europe and other sites. The "ZIKAction Kick Off" research meeting for the International ZIKAction Consortium was held at The University of the West 
Indies' (UWI) Vice Chancellery and Regional Head Quarters, in Kingston, Jamaica, on October 30 to November 2, 2016. Some 35 international researchers from Europe, Latin America, USA and the UWI's, Cave Hill and St Augustine Campuses, met with some 15-20 collaborators from the UWI's, Mona Campus and the Jamaican, Ministry of Health to discuss the implementation of the project (20). A legal memorandum of understanding has been signed between the UWI and the Jamaican, Ministry of Health. This permits formal collaboration between the UWI and the Jamaican, Ministry of Health to implement the protocol in Jamaica and data sharing between the parties, including international partners. The ZIKAction project will concentrate its efforts on the maternal and paediatric axis of ZIKV, chikungunya and dengue fever. The project will begin with the vertical transmission arm being implemented in three hospitals A, B and C and some selected feeder antenatal clinics. Hospital A is the largest maternity hospital in the English-speaking Caribbean, with approximately 7500 deliveries in 2016 among its patient population from the Kingston metropolitan region. Hospital B performed some 5000 deliveries that year for an urban catchment area, outside of Kingston. Hospital C is a University Teaching Hospital with some 1500 deliveries in 2016.

To educate paediatricians, obstetricians, related healthcare providers and students in training about this new illness and its complications in children and also to provide a background for the ZIKAction international research project, we are documenting the trends among the first few cases of microcephaly identified at these hospitals after the ZIKV epidemic began in Jamaica. We also report the phenotype of two of the most severely affected infants with microcephaly and arthrogryposis. Written permission was obtained from the infant's birth mothers at the UWI, for their photographs to be taken and used for the purposes of medical education and research.

\section{RESULTS}

In 2016, among the notifications to the Jamaican Ministry of Health that were related to arbovirus diseases 6726 fit the case definition for ZIKV, 407 fit the case definition for chikungunya and 2004 fit the case definition for dengue fever. There were a total of 203 laboratory confirmed ZIKV cases, seven confirmed cases of chikungunya and 159 confirmed cases of dengue virus (serotypes 3 and 4) infection. The initial trends of microcephaly observed by the clinicians practising in three urban delivery hospitals (A, B, C) are reported, as follows.

Hospital A: reported 15 full-term newborns with microcephaly, 10 were delivered between November 10, 2016 and January 6, 2017. All were full-term newborns with OFC ranging from 28.5 to $31.5 \mathrm{~cm}$, severe microcephaly with OFC's $<-3 \mathrm{Z}$ scores was seen in ten. Most $(12,80 \%)$ had the craniofacial phenotype of CSAZ: including overlapping sutures (9), bi-temporal narrowing, or biparietal depression (8), small anterior fontanelle (6), closed fontanelle (4), increased skin folds of neck, or scalp (3), occipital prominence (3), relatively large hands (2) and feet (1), arthrogryposis (1), congenital heart disease (1) hypertonia (3) and tremors (1). Lowbirthweight was present in four. Ten had neonatal intracranial ultrasounds which revealed grossly overlapping sutures and/or closed or small fontanelles (3), intracerebral calcifications (4), dilated and/or asymmetric lateral ventricles (4), cerebral atrophy (1), lack of frontal lobe sulcation and increased periventricular white matter (1). Computed tomography (CT) scans in two revealed calcifications, thinning of cortical mantle because of dilated ventricles (2). Nuclear magnetic resonance imaging (MRI) showed dilated ventricles and intracerebral calcifications (1 other). One newborn had OFC of $32 \mathrm{~cm}$, the craniofacial phenotype of CSAZ and ultrasonography with intracranial calcifications. Only four mothers reported symptoms consistent with ZIKV in pregnancy (rash with fever and/or joint pains). Toxoplasmosis, other agents, rubella, cytomegalovirus, herpes simplex virus titers were negative in five and ZIKV PCR testing (done by the $\mathrm{CDC}$ ) in one was negative. The rate of microcephaly was estimated as $0.8 \%(10 / 1212)$ live births.

Hospital B: In Hospital B, among 414/629 (65\%) of primarily term vaginal live births reviewed during eight weeks of

December to January 2017, 17 (4\%) had OFC's $\leq 32 \mathrm{~cm}$; eight patients had OFC $<-2 \mathrm{Z}$ score, six patients had OFC $<-3 \mathrm{Z}$ score and three patients had OFC at $-2 \mathrm{Z}$ score; 14 patients $(3 \%)$ were therefore microcephalic. Their OFCs ranged between 26 to $31.5 \mathrm{~cm}$. Seventeen others had relative microcephaly. Among the 14 microcephaly cases, five term newborns had low birthweight (1.9 to $2.49 \mathrm{~kg}$ ), three had seizures within 24 hours. Only one patient had a low APGAR score of $3^{1}$ and $6^{5}$ minutes. Three had seizures within 24 hours of life. All had severe microcephaly, two of these patients had cranial ultrasounds; both showed calcifications and lateral ventricular dilatation. Cerebral atrophy was demonstrated on the ultrasound of one patient and on the MRI of the other. One patient also had arthrogryposis. Maternal ages ranged between 15-43 years. Only one mother had a rash and her baby had severe microcephaly. All other mothers were asymptomatic and none had Zika virus testing done. Eleven of the 14 mothers had ultrasound done in pregnancy with only one showing an abnormality of head body size discrepancy. Two mothers had HIV coinfection and their babies both tested HIV-negative. Microcephaly rate was $1.63 \% \quad(14 / 857$ live births). Hospital C: Hospital C performed active surveillance for mothers who were symptomatic in pregnancy with rash, joint pains, fever, red eyes and identified 6\% (66/1180) such women during May 1, 2016 through March 31, 2017. Sixty-five per cent (43/ 66) have since delivered and $2.3 \%(1 / 43)$ had microcephaly (OFC $<31.4 \mathrm{~cm}<-2 \mathrm{Z}$ scores). Four others had low OFCs $(<33 \mathrm{~cm})$, but not in the range for microcephaly. Therefore, $84 \%(36 / 43)$ of babies born to symptomatic mothers had a normal OFC. Microcephaly rate for all newborns for the period was $2.2 \%(26 / 1180)$. The monthly rate varied from $0 \%$ to $5 \%(6 / 118)$ peaking in March. Fifty newborns deliveries from a symptomatic mothers also had low OFCs $(<33 \mathrm{~cm})$, but not in the range of microcephaly and these cases also peaked in March. 
Two mothers had HIV co-infection, their babies both tested HIV-negative. Hospital C also accepted babies with severe microcephaly and arthrogryposis from Hospitals A and $\mathrm{B}$ for specialist consultations and investigations. Multidisciplinary team management of babies probably included the obstetrician, neonatologist, infectious disease specialist, neurologist, neuro-radiologist, developmental pediatrician, physiatrist, orthopedist, audiologist, ophthalmologist, microbiologist, psychologist, social worker, nursing, public health and others. Case reports for the two most severely affected babies with microcephaly and arthrogryposis are reported as follows.

\section{Case report one}

SS is a seven-week-old female whose mother (MT) had six antenatal visits. She reported recurrent upper respiratory tract infections and exposure to mosquitoes, but was asymptomatic for arbovirus illness. She had a normal intrauterine fetal ultra-sonography at 16 weeks gestation. She had a spontaneous vaginal delivery at "Hospital B", cephalic presentation at 41 weeks gestation. The APGAR scores were $7^{1}$ and $9^{5}$ minutes, respectively. Examination at birth was significant for weight $2.53 \mathrm{~kg}(<-3 \mathrm{Z}$ scores $)$, length $48 \mathrm{~cm}(<-2 \mathrm{Z}$ scores $)$ and OFC $26 \mathrm{~cm}(<-3 \mathrm{Z}$ scores $)$.

Dysmorphic features included severe microcephaly, prominent occiput, bitemporal narrowing, collapsed skull bones, small anterior fontanelle, low posteriorly-rotated ears, bilaterally, horizontal nystagmus, redundant skin folds at the nape, wide spaced nipples and large hands with clinodactyly. She had respiratory distress and generalized cracking and peeling of the skin. There was hypertonia evident in the upper limbs with brisk reflexes throughout. The musculoskeletal system revealed severe arthrogryposis with hand and feet contractures, flexion deformities of both hips, hyperextension of the knees, with inability to dorsiffex with severe restriction in abduction, positive Barlow's, hypertonia and hypereflexia of the upper limbs, "rocker-bottom" feet with prominent cal- caneii, sandals gap and abnormal creases on the soles. She also had displaced anus with lax anal tone.

She was diagnosed as CSAZ with severe microcephaly and arthrogryposis and admitted to the Newborn Intensive Care Unit. Hospitalization was significant for neonatal seizures on day one, which was managed with phenobarbitone.

Respiratory distress responded eventually on oxygen at $5 \mathrm{~L} /$ minute by face mask. Cranial ultrasound revealed overlapping sutures, limiting visualization of the brain parenchyma. Dilated lateral ventricles and multiple tiny calcifications in the right frontal lobe were evident, with normal third and fourth ventricles. Hip ultrasound revealed laxity of both hips, with femoral head bulging in the fibrous labrum, bilaterally.

On re-evaluation at hospital $\mathrm{C}$ at age six weeks, neurological consultations confirmed the dysmorphisms and revealed additional features of irritability, bi-frontal facial narrowing, wide nasal bridge, mild retrognathia, high arched palate, diastasis of recti abdominis, small umbilical hernia, external rotation of the hips, hyper-extension at the knees, extra crease beneath patella of both knees, wasting of left lower limbs distally $>$ more than proximally, shortening of the left lower limbs, fixed contractures to knees, distal tapering of fingers, clinodactyly, flat feet, overlapping toes, prominent calcaneii with "rocker bottom feet", hypertonia and hyper-reflexia to upper limbs and generalized xeroderma facial rash (Figs. $1 \mathrm{~A}-\mathrm{C})$.

Ophthalmology consultation revealed bilateral optic atrophy. Nuclear MRI of the head and brain revealed collapsed skull bones. There was global hemispheric parenchymal volume loss, most significant posteriorly and in the temporal lobes. There was decreased salivation as well as sub-cortical parenchymal calcifications. There was dysgenesis of the corpus callous with associated colpocephaly as well as hypoplasia of the inferior vermis with wide communication between the fourth ventricle and a mega cisterna magna (Dandy Walker variant). Thin septations were noted in the occipital horns of the lateral ventricles (Figs. $1 \mathrm{D}$ and E). Results of mother and
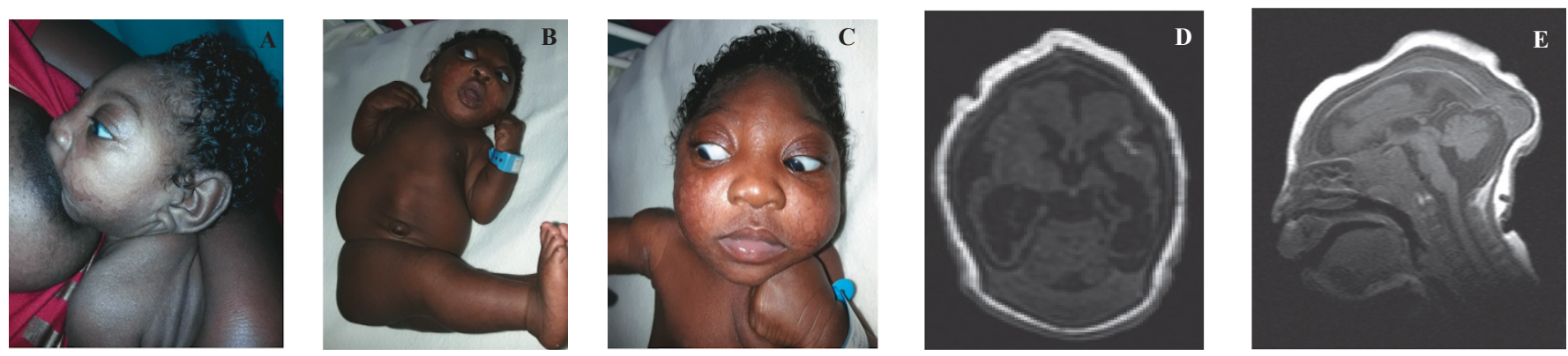

Fig. 1: Panels (1A, B, C above) show female infant at age six weeks (sucking at mother's breast), showing severe microcephaly, sloping forehead, facial dysproportion with "over sized" facial features, appearance of proptosis, horizontal nystagmus with bilateral optic atrophy. Infant also displays clenched upper limbs with cortical fisting, diastasis of "recti abdomini" muscles, severe arthrogryposis and "rocker bottom" feet.
Panels (1D, E above) reveal infant's magnetic resonance imaging of the skull and brain displaying marked microcephaly, collapsed skull bones with extensive scalp folding. There is decreased hemispheric parenchymal volume loss with decreased salvation and evidence of calcification (D). There are septations in the occipital horns of the lateral ventricles as well as evidence of a vermian hypoplasia, in keeping with a Dandy Walker variant. 
infant were identical for ZIKV and dengue serologies: DENV NS1 antigen - negative, DENV IgM - negative, Dengue IgG - positive, ZIKV IgM - negative, ZIKV IgG - positive. Mother's HIV and Syphilis serologies were negative. ZIKV PCR of infant's urine and blood remains outstanding.

She is receiving ambulatory management by orthopaedics, early stimulation center, infectious diseases, neurology and ophthalmology. She now lives with her mother and maternal grandparents and she is breastfed.

\section{Case report two}

JB is a six-week-old male whose mother $(\mathrm{KJ})$ gave an antenatal history significant for rash, fever and joint pains at 4/40 gestation. He was delivered spontaneously at "Hospital A" at term (37 weeks and 6 days) gestation. His APGAR scores were $4^{1}, 6^{5}$, respectively and he required resuscitation.

JB had multiple congenital anomalies at birth including severe microcephaly -OFC $28.0 \mathrm{~cm}<-3 \mathrm{Z}$ scores; severe intrauterine growth retardation with low birthweight of $2.02 \mathrm{kgm}<$ $-3 \mathrm{Z}$ scores; length $48 \mathrm{~cm}<-3 \mathrm{Z}$ scores. Systemic involvement included, multiple abnormalities including; the neurological system with CT scan of the brain revealing microcephaly with cortical atrophy, severe ventriculomegaly of the lateral and third ventricles, fine calcifications in the thalami and basal ganglia bilaterally and in the frontal lobes. A huge posterior fossa cyst was noted in communication with the $4^{\text {th }}$ ventricle, consistent with Dandy Walker syndrome and aqueductal stenosis.

There were multiple dysmorphisms with facial disproportion, redundant scalp skin, overlapping cranial sutures, comparatively large ears and face, posteriorly rotated right more than left ears, bitemporal narrowing and horizontal nystagmus. Respiratory system showed hypoplasia of the right lung with abnormal lobulations, elevation of the diaphragm, associated with respiratory distress syndrome at birth. He required hospitalization for over four weeks in the Newborn Special Care Unit and over one-week on the Paediatric Service, where he remained oxygen dependent with a baseline respiratory distress of 50-80 breaths/minutes and intercostal recessions. Cardiovascular findings by echocardiogram showed a small patent ductus arteriosus along with a small inter-atrial communication of an atrial septal defect and elevated pulmonary pressures. Abdominal abnormalities included gastrooesophageal reflux and a right inguinal hernia. There was a patulous anus. Genital examination showed bilateral cryptorchidism and chordee of the penis (Fig. 2E).

Musculoskeletal system revealed severe congenital arthrogryposis with multiple limb contractures characterized at birth with fixed flexion and adduction deformities in limbs, both knees hyperextended, right internally rotated, left externally rotated, with camptodactyly (middle three digits), clinodactyly, overlapping fingers and prominent calcaneii with "rocker bottom feet" (Figs. 2 A, C and E). Subsequently the child developed fixed adduction of arms, internally rotated at the

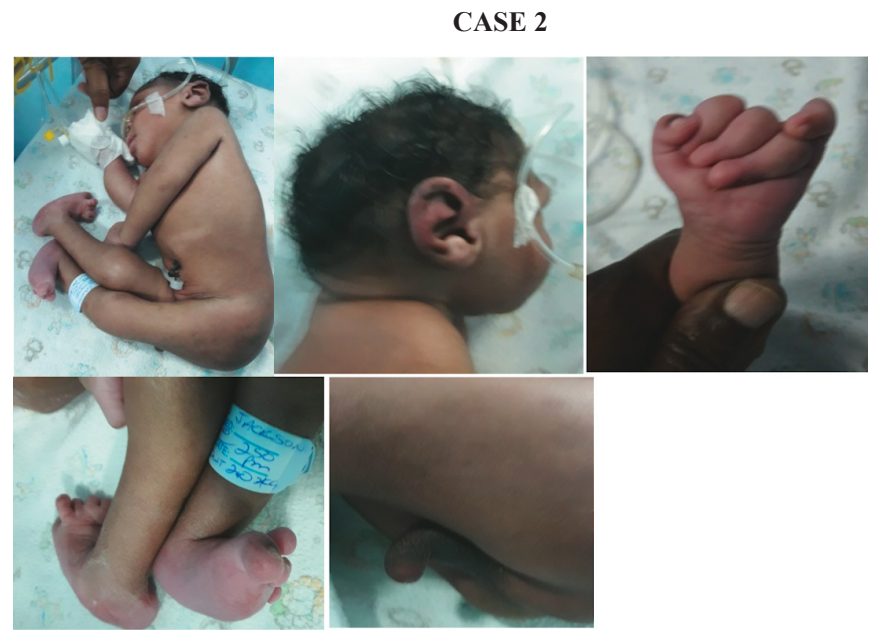

Fig. 2: $\quad$ Panels (2A, B, C, D, E)- show male newborn on day three of life with severe microcephaly, collapsed skull with prominent occiput and severe arthrogryposis, involving multiple joints, with dislocated knees and hips, prominent calneii (rocker bottom feet), camptodactyly (permanently bent fingers, toes), clinodactyly (curved fingers and toes), chordee penis (penis curved downwards), bilateral crytorchidism (undescended testes) and brachydactyly of the toes (shortened toes).

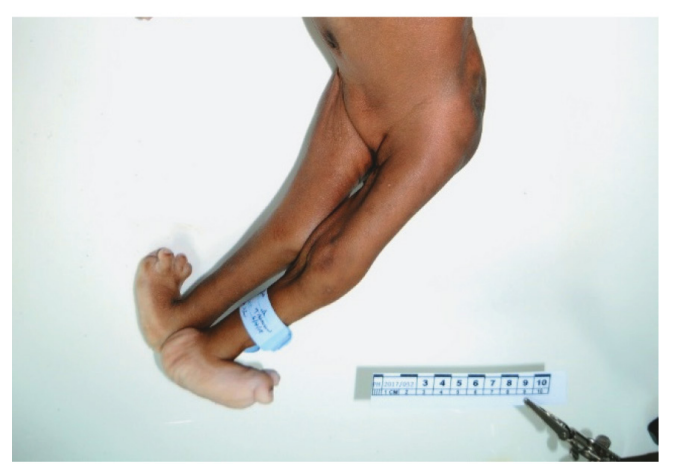

Fig. 3A: External autopsy photograph. Severe congenital arthrogryposis with joint deformities and marked muscle wasting.

shoulder, extended at the elbow, "frozen hips" and knees, bilaterally (Fig. 3A).

He was referred to "Hospital C" at age four weeks for further consultations. He was noted to have persistent respiratory distress. He also had a hoarse cry and was evaluated by the Otolaryngology Service for vocal cord dysfunction. Arterial blood gases showed a relative hypercarbia and hypoxaemia off oxygen. He was therefore maintained on $1 \mathrm{~L} \mathrm{O}_{2}$. Throughout the course of his hospitalization, he was noted to have an increasing requirement for oxygen with no change in his other clinical parameters and no worsening of his chest radiographic findings. He required enteral feeds via a naso-gastric tube due to a weak suck and poor gag reflex. At age six weeks, he developed worsening respiratory distress associated with oxygen desaturations. Despite increased concentration of oxygen, control of seizures with anti-epileptic medications, 
bag valve ventilation with intermittent positive pressure ventilation, intubation and continuous positive airway pressure, resuscitative efforts failed and he died. Significant investigations included CMV IgM: negative; toxoplasmosis IgM: negative; rubella IgM: negative; dengue IgM: negative; HIV: negative; Sickle Cord Blood: A + A2. Karyotyping showed normal male (thus, excluding Trisomy 18). Autopsy confirmed his aforementioned physical findings (Fig. 3B). Investigations for blood, urine, spinal cord and brain for ZIKA PCR are pending at the time of manuscript submission.

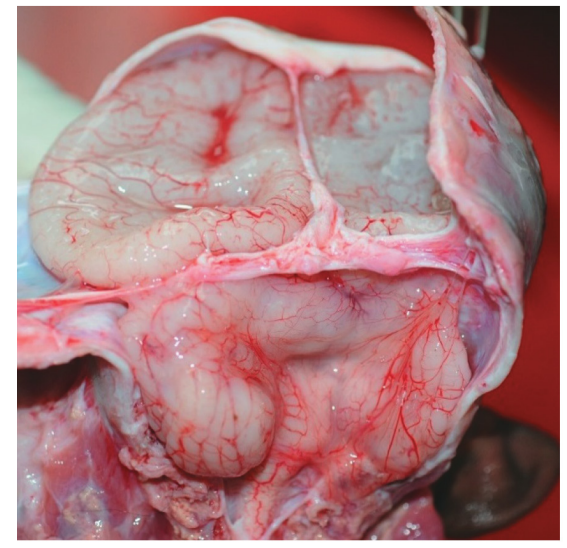

Fig. 3B: Autopsy photograph of opened cranial vault, posterior view. Ruptured posterior fossa cyst with absence of the cerebellar vermis consistent with Dandy-walker malformation. There is also marked hydrocephalus with thinning of the cerebral cortex.

Source: ZIKA V Microcephaly in Jamaica, VJH, STH, UHWI, 14 Feb; 30 Apr; 8, 23, 24, 25, 27, 29, 30, 31 May, 2017; 1, 2, 3 Jun, 2017

\section{DISCUSSION}

Microcephaly is not new to Jamaica (21). However, since the 2016 ZIKV epidemic, several newborns with the characteristics of CSAZ, including: microcephaly with craniofacial disproportion, neuro-imaging and autopsy findings as well as arthrogryposis are now being recognized in urban settings in Jamaica. A trend towards babies being delivered with low head circumferences at birth, but not yet in the range of microcephaly and still others with normal head sizes who were born to women who were symptomatic in pregnancy are also being observed. In addition, the majority of the babies with possible CSAZ are being born to asymptomatic women who did not report any symptoms related to arbovirus illness (ie, rash, fever and joint pains) in pregnancy. The USA's Centers for Diseases Control and Prevention along with the American Academy of Pediatrics as well as recent guidelines issued from Brazil's Ministry of Health have all called for increased recognition, or expanded case surveillance definitions with treatment and care of this diverse group of affected infants $(12,22,23)$.

As of May 17, 2017, there were 837 surveillance notifications to the Jamaican, Ministry of Health from mothers who reported symptomatic illness in pregnancy, with 707 (84\%) suspected reports meeting ZIKV clinical case definition and 75 laboratory-confirmed cases. Notified cases of CSAZ totaled: 181 and 52 were suspected CSAZ, comprising other congenital anomalies four; microcephaly 48 , with non-severe cases of 36 , severe cases of 12 , probable cases of three and confirmed cases none. All of these babies were reported to be living with their mothers.

ZIKV displays broad tissue tropism, including the nervous tissue with clinical effects most pronounced when the mother is infected during early pregnancy (24-26). These cases appear characteristic of CSAZ (4-8). Prominent features included; severe microcephaly with flattening, or sloping of the forehead, overlapping sutures, closed anterior fontanelles, pointed occiput, relative enlargement of the face and ears, excess skin folds on the scalp and neck, arthrogryposis and seizures. The two case reports included these features and other characteristics of CSAZ. These included, neuroimaging and/or autopsy confirmation of several other supporting findings of multiple calcifications, abnormal gyral patterns, ventriculomegaly, prominent extra-axial spaces, hypoplasia of the brainstem and cerebellum and callosal dysgenesis $(8,27,28)$. Several other features that seem new to the literature, including chordee of the penis and cryptorchidism, possibly linked to arthrogryposis with flexion of the hips in utero limiting testicular descent. Similarly, an abnormal chest wall and pulmonary hypoplasia with persistent neonatal respiratory distress leading to ultimate demise, as reported here, could be due to oligohydramnios. "Rocker bottom feet" were present in both severely affected babies and have not been previously described. While congenital heart disease was evident, it is unclear whether this is related to CSAZ, or simply consistent with background rates of congenital heart disease in the population. Optic atrophy was also seen, while macular scarring and focal retinal pigmentation, although rare, are more consistently reported with CSAZ $(29,30)$. Outstanding research questions include whether these features comprise the full CSAZ syndrome and whether there are other risk factors. A case control study is now being conducted to better characterize these patterns. Data will be collated internationally, including here in Jamaica, an Island-population, congruent with the "ZIKAction PEDS" research work package, to augment the one other published case control study $(31,32)$.

Infant microcephaly has a multi-factorial aetiology. There is clinicopathological and experimental evidence indicating neurotrophic properties of Zika virus $(33,34)$. The virus has been identified in infected brain tissue at electron microscopy and its entire genome has been isolated from infected neuronal tissue (35). The virus appears to cause severe neuronal injury which is evidenced by diffuse astrogliosis and calcifications. While several of these babies have the characteristic phenotype of CSAZ, there is as yet no conclusive laboratory evidence linking any of these microcephalic babies to ZIKV-infection. Molecular diagnostics (usually ZIKV PCR) are required to meet WHO criteria. Even when performed, specific ZIKV PCR test from newborn and CSF samples can still be negative in live-born cases (8). Mothers with infants who have CSAZ, may demonstrate a positive ZIKV reverse transcription-polymerase chain reaction (RT-PCR) 
for up to 100 days (36). Results of current serologic testing (IgM and $\operatorname{IgG}$ ) in Jamaica have been challenging to resolve because of issues related to cross reactivity, most likely due to similarities between the envelope proteins of dengue and ZIKV flaviviruses, as well as previous dengue exposure (37). These cases are therefore characterized as "probable" cases of CSAZ, as has also been reported for the majority of other published reports (4-8). Diagnostics also need to be developed and be responsive to asymptomatic mothers, who may have babies who are either born with CSAZ, or develop characteristic features later on. Diagnostics also need to be improved for babies with possible CSAZ. Microcephaly has also been found among children with vertically-acquired chikungunya fever (38). Dengue, chikungunya and ZIKV can be transmitted from mother-to-child in pregnancy and intrapartum and the complications of oligohydramnios, preterm delivery, low birthweight, miscarriage and infant microcephaly have been reported with chikungunya and ZIKV. Dengue, chikungunya and ZIKV all have shown attributable morbidity in Jamaican children (39-41). Dengue, of itself, has not been reported as a cause microcephaly (42). Clarification is still needed to determine if a previous, or current dengue co-infection, maybe a facilitator that augments the congenital anomalies attributed to ZIKV.

Babies with CSAZ are known to have early growth restriction and neuro-developmental challenges (6). Severe neuro-developmental anomalies are also possible long-term, including poor balance, coordination, motor development, speech, hyperactivity, seizures, reduced hearing, sight and swallowing reflexes would be expected; growth restriction is expected with poor feeding and swallowing, short stature and failure to thrive. These babies would also have educational and learning challenges. Other long-term concerns include, multiple and recurrent hospitalizations, recurrent aspiration pneumonias, other infections and related challenges.

Infants are to be evaluated for intracranial neurological abnormalities with cranial ultrasound and for those with a closed anterior fontanelle, nuclear MRIs, or CT scans. Similarly, the TORCHS and other arboviral perinatal infections are to be excluded. Team management should be multidisciplinary involving highly specialized services, including the obstetrician, neonatologist, infectious disease specialist, neurologist, neuro-radiologist, developmental paediatrician, physiatrist, orthopaedist, audiologist, ophthalmologist, microbiologist, psychologist and social worker to facilitate the best possible outcomes.

Long-term care should also embrace a holistic multidisciplinary, collaborative team approach - similar to our HIV treatment and care model $(43,44)$. Long-term management should include: a research programme with standardized data extraction instruments, database, data management and information technology personnel. The team would comprise paediatricians, neurologists, developmental specialists, nutritionists, speech therapists, social workers, research nurses, orthopaedists, physiotherapists, special educators and others.
Ideally, family-based care with appropriate maternal support should be considered. Facilities for state care, similar to the HIV model should also be embraced. However, the capacity to provide optimal care for these babies, in high numbers, needs to be considered, as this relates to health, maintenance and other economic costs. The Ministry of Health has established a fund for caring for these vulnerable infants for the first 18 months of life. Similar to HIV and children with other severe neurological abnormalities, it is anticipated that a subset of these children will most likely be abandoned in hospital and will therefore require long-term institutional care.

The main limitation is absence of confirmed ZIKV diagnostics in mothers and babies. Results of PCR testing of blood, urine, CSF, spinal cord, or brain are outstanding due to interruption of service for this laboratory test at the time of manuscript submission. The presence of ZIKV in the CSF is currently the gold standard for proving CNS infection in affected babies. Similarly, infant infection can be predicted if ZIKV is isolated from mother's amniotic fluid. There are also limitations in current methodologies for serologic diagnosis of ZIKV-infections in asymptomatic mothers and babies, especially in the settings of dengue co-circulation. Although most babies had characteristic features of CSAZ, results of evaluations for TORCH infections were not always available. Measurements of the OFC also appeared to be biased towards rounding to $0.5 \mathrm{~cm}$, or up to a whole number, instead of recording to within one decimal place. This study was also biased towards describing infants with the most severe CSAZ phenotypes of severe microcephaly and severe arthrogryposis. Jamaica experienced a ZIKV outbreak in 2016, while chikungunya and dengue were also co-circulating. Clinicians are now seeing cases of microcephaly and a trend towards decreasing head circumferences in some babies. Some newborns, most of whom were born to asymptomatic mothers, showed distinct classical characteristics of ZIKV congenital syndrome (CSAZ). While many others, with normal OFCs, are being delivered to mothers who were symptomatic in pregnancy. Jamaica has yet to confirm its first case of congenital syndrome linked to ZIKV (PCR) isolation. Notwithstanding, these babies require a coordinated, multidisciplinary system of holistic care with access to family counselling and support. This will be challenging and costly for developing countries, such as Jamaica, to successfully implement while still necessary to improve the neurodevelopmental potential of this new and vulnerable population of children.

\section{REFERENCES}

1. Pan American Health Organisation: World Health Organisation. Epidemiological alert: neurological syndrome, congenital malformations and Zika virus infections: implications for public health in the Americas. http://www.paho.org/hq/index.php?option=comdocman\&task=doc down load\&Itemid=\&gid=32405\&lang=en. Published December 1, 2015. Ac-cessed 5 May, 2017.

2. Chan M. WHO Director-General summarizes the outcome of the Emergency Committee on regarding clusters of microcephaly and Guillain Barre syndrome. 1 February, 2016. www.who.int/mediacentre/ 
news/statements/2016/emergency-committee-zika-microcephaly/en/ Accessed 22 May, 2017.

3. Rasmussen S, Jamieson DJ, Honein MA, Peterson LR. Zika and birth defects - reviewing the evidence for causality. N Engl Jour Med April 13, 2016 DOI.10.1056/NEJMsr1604336.

4. Microcephaly Epidemic Research Group. Microcephaly in infants, Pernambuco State, Brazil, 2015. Emerg Infect Dis 2016: 22: 1090-3.

5. Schuler-Faccini L, Ribeiro EM, Feitosa IM. Brazilian Medical Genetics Society-Zika Embryopathy Task Force: possible association between Zika virus infection and microcephaly, Brazil, 2015. MMWR Morb Mort Wkly Rep 2016; 65: 59-62.

6. Silva AAM, Ganz JSS, Sousa PS, Doriqui MJ, Ribeiro RC, Remedios $\mathrm{M}$ et al. Early growth and neurologic outcomes of infants with probable congenital ZIKA virus syndrome. Emerg Infect Dis. DOI:10.3201/ eid2211.160956.

7. del Campo M, Feitosa IM, Ribeiro EM, Horowitz DD, Pessoa AL, Franca $\mathrm{GV}$ et al. The phenotypic spectrum of congenital Zika syndrome. Am J Med Genet 2017; 9999: 1-17.

8. Moore CA, Staples EJ, Dobyns WB, Pessoa A, Ventura CV, da Fonseca $\mathrm{EB}$ et al. Characterising the pattern of anomalies in congenital Zika syndrome for pediatric clinicians. JAMA Pediatr Review. Published online November 3, 2016. doi:10.1001/jamapeds.2016.3982

9. Calvet G, Aguiar RS, Melo AS, Sampaio SA, de Filippis I, Fabri A et al. Detection and sequencing of Zika virus from amniotic fluid of fetuses with microcephaly in Brazil: a case study. Lancet ID, 2016; 16: 653-60.

10. Russell LJ, Weaver DD, Bull MJ, Weinbaum M. In utero brain destruction resulting in collapse of the fetal skull, microcephaly, scalp rugae and neurologic impairment. The fetal brain disruption sequence. Am J Med Genetics 1984; 17: 509-21.

11. Carona-Rivera JR, Corona-Rivera E., Romero-Velarde E, HernandezRocha J, Bobadilla-Morales L, Corona-Rivera A. Report and review of the fetal brain disruption sequence. Eur J Pediatr 2001; 160: 664-7.

12. Granca GVA, Schuler-Faccini L, Oliveira WK, Henriques CM, Carmo EH, Pedi VD et al. Congenital Zika virus syndrome in Brazil: First 1501 live births with complete investigation. Lancet 2016; 388: 891-7.

13. Van der Linden V, Pessoa A, Dobyns W, Barkovich AJ, van der Linden Jnr H, Leite Rolim Filho EL et al. Description of 13 Infants Born During October 2015-January 2016 With Congenital Zika Virus Infection Without Microcephaly at Birth - Brazil. MMWR Morb Mortal Wkly Rep 2016; 65:1343-8.

14. WHO Zika Situation Report, Zika Virus, microcephaly and Guillain Barre syndrome. 10 March, 2017.http://apps.who.int/iris/bitstream/10665/ 254619/1/WHO-ZIKV-SUR-17.1-eng.pdf. Accessed 15 March, 2017.

15. Webster-Kerr K, Christie CDC, Grant A, Chin D, Burrowes H, Clarke K, Wellington I, Shaw, K, De La Haye W. Emergence of the Zika virus epidemic in Jamaica and the national response. West Indian Med J 2016; 65: 243-9.

16. Metsky HC, Matranga CB, Wohl S, Schaffner SF, Freije CA, Winnicki SM et al. Zika virus and sperad in the Americas. Nature (2017), doi: 10.1038/nature22402; Received 01 March 2017; Accepted 02 May 2017; Published online - 24 May 2017

17. Ministry of Health, Jamaica. Zika preparedness and response plan for out-break control. Epidemiology Surveillance Plan, 24 May, 2015 Revision 5: 14 December, 2015

18. PAHO/WHO. Guidelines for surveillance for Zika virus and its complications. 2016.

19. Villar J, Cheikh Ismali L, Victora CG, Ohuma EO, Bertino E, Altman DG et al. International standards for newborn weight, length and head circumference by gestational age and sex. The newborn cross sectional study of INTERGROWTH $21^{\text {st }}$ project. Lancet 2014; 384: 857-68. https://intergrowth21.tghn.org/site_media/media/articles/newbornsize. pdf

20. Christie CD, Giaquinto C. Unravelling the Zika virus epidemic through population based research. West Indian Med J 2016; 65: 239-42.

21. Samms-Vaughan M, Thame M, Osmond C, Hambleton IR, McCawBinns A, Ashley DE et al. Growth curves for normal Jamaican Neonates. West Indian Med J 2006; http://dx.doi.org/10.1590/S0043-314420060 00600002
22. CDC. Interim guidance for the evaluation and management of infants with possible congenital Zika virus infection. Morb Mort Wkly Rep MMWR 2016.

23. Brazilian Ministry of Health (May, 2017). Integrated guidelines for surveillance and health care in the context of the Public Health Emergency of National Concern; Procedures for monitoring changes in growth and development from gestation to early childhood, related to Zika virus infection and other infectious diseases within the operational capacity of the SUS. Source: http://portalarquivos.saude.gov.br/images/pdf/2016/ dezembro/12/orientacoes-integradas-vigilancia-atencao.pdf. Accessed, 23 May, 2017.

24. Garcez PP, Loiola EC, Madeiro da Costa R, Higa LM, Trindade P, Delvecchio R et al. Zika virus impairs growth in human neurospheres and brain organoids. Science. 2016: 352: 816-8.

25. El Costa H., Jordi Gouilly J, Mansuy JM, Chen Q, Levy C, Cartron G, et al. ZIKA virus reveals broad tissue tropism during the first trimester of pregnancy. Scientific Reports 2016; 6: 35296 DOI: 10.1038/srep35296. Accessed, 25 May, 2017.

26. Kleber de Oliveira W, Cortez-Escalante J, De Oliveira WT, do Carmo GM, Henriques CM, Coelho GE et al. Increase in reported prevalence of microcephaly in infants born to women living in areas with confirmed zika virus transmission during the first trimester of pregnancy - Brazil, 2015. MMWR Morb Mortal Wkly Rep 2016; 65: 242-7. DOI: http:// dx.doi.org/10.15585/mmwr.mm6509e2. Accessed, 25 May, 2017.

27. De Fatima Vasco Aragao M, van der Linden V, Brainer-Lima AM, Coeli RR, Rocha RR, da Silva PS et al. Clinical features and neuroimaging (CT and MRI) findings in presumed Zika virus related congenital infection and microcephaly: retrospective case series study. BMJ 2016; 353: 1901.

28. Soares de Oliveira-Szejnfeld P, Levine D, de Oliveira Melo AS, Ramos Amorim MM, Batista AGM, Chimelli L et al. Congenital Brain Abnormalities and Zika Virus: What the Radiologist Can Expect to See Prena-tally and Postnatally. Radiol 2016; 281: 203-18; 10.1148/radiol. 2016161584.

29. De Paule Freitas B, de Oliveira Dias JR, Prazeres J, Sacramento GA, Ko AI, Maia $\mathrm{M}$ et al. Ocular findings in infants with microcephaly associated with presumed Zika virus congenital infection in Salvador, Brazil. JAMA Ophthalmol 2016. 0267. doi:10.1001//jamaophthalmology.

30. Miranda HA II, Costa MC, Frazao MA, Simao N, Franchischini S, Moshfeghi DM. Expanded spectrum of congenital ocular findings in microcephaly with presumed Zika infection. Ophthalmol 2016; 123: 1788-94.

31. De Araujo TV, Rodriques LC, De Alencar Ximenes RA, M. Investigators from the Microcephalyiranda-Filho D, Montarroyos UR, Lopes de Melo AP, et al. Epidemic Research Group; Brazilian Ministry of Health PAHO, Institute of Medicine, State Health Department of Pernambuco. Association between Zika virus infection and microcephaly in Brazil, January to May, 2016: preliminary report of a case control study. Lancet Infect Dis doi: 10.1016/S1473-3099(16)30318-9.

32. Gerardin P, Randrianaivo H, Schaub B, Cesaire R, Doray B, LeBeaud $\mathrm{AD}$. Congenital ZIKA syndrome: time to move from case series to case control studies and data sharing. BMJ 2016; 354: 4850.

33. Mlakar J, Korva M, Tul N, Popović M, Poljšak Prijatelj M, Mraz J et al. Zika Virus Associated with Microcephaly. N Engl J Med 2016; 374: 951-8. DOI: 10.1056/NEJMoa1600651

34. Fabiele Baldino Russo FB, Jungmann P, Beltrão B, Braga PC. Zika infection and the development of neurological defects. Cellular Microbiol 2017; 19: e12744. https://doi.org/10.1111/cmi.12744

35. Tang H, Hammack C, Ogden SC, Wen Z, Qian X, Li Y et al. Zika virus infects human cortical neural progenitors and attenuates their growth. Cell Stem Cell 2016; 18: 587-90.

36. Suy A, Sulleiro A, Rodó C, Vázquez E, Bocanegra C, Molina I. Prolonged Zika Virus Viremia during Pregnancy. N Engl J Med 2016; 375: 2611-3.

37. Priyamvada L, Quicke KM, Hudson WH, Onlamoon N, Sewatanon J, Edupuganti.S. Human antibody responses after dengue virus infection are highly cross-reactive to Zika virus. PNAS, 2016; 113: 7852-7. 
38. Gérardin P, Sampériz S, Ramful D, Boumahni B, Bintner M, Alessandri J-L et al. Neurocognitive outcome of children exposed to perinatal mother-to-child chikungunya virus infection: the CHIMERE Cohort Study on Reunion Island. PLoS Negl; Trop Dis 2014; 8: e2996. https:// doi.org/10.1371/journal.pntd.0002996.

39. Melbourne-Chambers R, Christie CD, Greenaway E, Bullock R. Neurological Syndromes in Children during the Zika virus and dengue fever outbreak in Jamaica. West Indian Med J 2016; 65: 425-30.

40. Christie CD, Melbourne -Chambers R, Ennevor J, Young-Peart S, Buchanan T, Scott-Brown P et al. Chikungunya fever in Jamaican children: public health effects and clinical features. West Indian Med J 2016; 65: 431-7.

41. Davidson T, Vickers I, Christie CD. Outcomes of dengue in Jamaican children. West Indian Med J 2016; 65: 442-9.
42. Nascimento LB, Siqueira CM, Coelho GE, Siqueira JB. Symptomatic dengue infection during pregnancy and live birth outcomes in Brazil, 2007-13: a retrospective observational cohort study. Lancet Infect Dis 2017 Published Online May 18, 2017 http:// dx.doi.org/10.1016/ S1473-3099(17)30169-X.

43. Christie CD, Pierre RP. Eliminating vertically-transmitted HIV/AIDS while improving access to treatment and care for women, children and adolescents in Jamaica. West Indian Med J 2012; 61: 396-404.

44. Christie CD, Palmer PM, Tomlinson J, Green-Douglas T, Hamilton M, Pierre RP et al. Achieving elimination of vertical transmission of HIV in Jamaica. Annals of Public Health Research 2017; 4: 1061-9. 